\title{
Comparison of Some Biochemical Properties of Epidermis in Tumor Promotion-Susceptible and -Resistant Strains of Mice
}

\author{
Satoshi YAMAMOTO, Itsumi KIYOTO, Eriko AIZU, \\ Nobuyuki SASAKAWA, Toshio NAKAKI and Ryuichi KATO \\ Department of Pharmacology. School of Medicine, Keio University, \\ 35 Shinanomachi. Shinjuku-ku, Tokyo 160, Japan \\ Accepted February 3. 1988
}

\begin{abstract}
It has been reported that CD-1 and SENCAR mice are susceptible and C57BL/6 mice are resistant to skin tumor promotion caused by phorbol esters. Specific binding of a phorbol ester to its epidermal receptor site, epidermal protein kinase $C$ activity, and ornithine decarboxylase (ODC) induction in epidermis were compared between tumor promotion-susceptible and -resistant strains of mice. Specific binding of $\left[{ }^{3} \mathrm{H}\right] 12$-O-tetradecanoylphorbol-13-acetate (TPA) to the particulate fraction of the epidermis of $\mathrm{C} 57 \mathrm{BL} / 6$ mice gave a similar dissociation constant $\left(K_{d}\right)$ and a maximal number of binding sites $\left(B_{m a x}\right)$ to those of CD-1 mice. Protein kinase $\mathrm{C}$ activity of the epidermal $105,000 \times \mathrm{g}$ supernatant was not significantly different between $\mathrm{C} 57 \mathrm{BL} / 6$ and $\mathrm{CD}-1$ mice. Protein kinase $\mathrm{C}$ activity of the $105,000 \times \mathrm{g}$ pellet, however, was significantly higher in C57BL/6 mice than in CD-1 mice. A topical application of TPA to the skin caused epidermal ODC induction in all of these strains of mice. At any doses of TPA. TPA-induced epidermal ODC activity of C57BL/6 mice was always higher than those of SENCAR and CD-1 mice. Maximal induction of epidermal ODC by TPA was also highest in $\mathrm{C} 57 \mathrm{BL} / 6$ mice among these three strains of mice. These results indicate that the mechanism of the difference in susceptibility of C57BL/6, CD-1 and SENCAR mice to the tumor-promoting action of TPA resides in a step distal to or other than the protein kinase $C$ activation and ODC induction.
\end{abstract}

Susceptibility to two-stage skin carcinogenesis by initiation and promotion is different according to the strains of mice (1). Some strains of mice are susceptible to the tumor-promoting action of phorbol esters such as 12-O-tetradecanoylphorbol-13acetate (TPA), but some strains are far less susceptible (1). In this regard. C57BL/6 mice appear to be refractory to the tumor-promoting action of TPA (1-3). On the other hand. CD-1 and SENCAR mice are susceptible to TPA-caused tumor promotion (1-3). Little is known of the cellular basis for the difference in susceptibility. TPA-type promoters have been shown to alter many biochemica! events in mouse skin including the induction of ornithine decarboxylase (ODC) activity $(4,5)$, which is believed to be one of the essential factors for tumor promo- tion. Binding of TPA to its cellular receptor results in the activation of protein kinase $C$, and protein kinase $\mathrm{C}$-induced protein phosphorylation may mediate the tumor-promoting action of TPA $(6,7)$. In attempting to define the basis for the difference in susceptibility, we compared the receptor binding of $\left[{ }^{3} \mathrm{H}\right]$ TPA, protein kinase $\mathrm{C}$ activity and ornithine decarboxylase induction in tumor promotionsusceptible and -resistant strains of mice.

\section{Materials and Methods}

In vivo experiments: Female C $57 \mathrm{BL} / 6$, CD-1 and SENCAR mice, 7-8 weeks of age. were used. The dorsal hair of each mouse was shaved as described previously (8). Mice were topically treated with $200 \mu$ l of acetone containing the indicated amounts of TPA. Five hours after TPA application, the mice 
were killed by cervical dislocation and the epidermis was separated by a brief heat treatment (9). The ODC activity of the soluble epidermal supernatant was determined by measuring the release of ${ }^{4} \mathrm{CO}_{2}$ from $\left[1-{ }^{14} \mathrm{C}\right]$ ornithine as described previously (10).

$\left[{ }^{3} \mathrm{H}\right]$ TPA binding studies: Mouse epidermis was homogenized in 10 volumes $(W / v)$ of 50 $\mathrm{mM}$ Tris-HCl buffer ( $\mathrm{pH} 7.5$ ) with a Polytron homogenizer. The homogenate was centrifuged at $10.000 \times \mathrm{g}$ for $30 \mathrm{~min}$ at $4^{\circ} \mathrm{C}$, and the supernatant was centrifuged again at $105,000 \times \mathrm{g}$ for $60 \mathrm{~min}$. The resultant pellet was resuspended in $50 \mathrm{mM}$ Tris- $\mathrm{HCl}$ buffer $(\mathrm{pH} 7.5)$ and used for the binding assay. The samples $(60 \mu \mathrm{g} / \mathrm{ml}$ protein: final concentration) were incubated with various concentrations $(0.125-3 \mathrm{nM})$ of $\left[{ }^{3} \mathrm{H}\right]$ TPA in $50 \mathrm{mM}$ Tris- $\mathrm{HCl}$ buffer ( $\mathrm{pH} 7.5$ ) supplemented with $4 \mathrm{mg} / \mathrm{ml}$ bovine serum albumin at $39^{\circ} \mathrm{C}$ for $20 \mathrm{~min}$. For separating bound from free $\left[{ }^{3} \mathrm{H}\right]$ TPA, a membrane filtration technique was performed with use of cold acetone just as described previously (11). Nonspecific binding was defined as the counts observed in the presence of 0.5 " $\mathrm{M}$ TPA. Specific binding was defined as the total binding minus the nonspecific binding.

Assay of protein kinase $C$ activity: Epidermis was homogenized in 3 volumes $(w / v)$ of $20 \mathrm{mM}$ Tris- $\mathrm{HCl}$ buffer ( $\mathrm{pH} 7.5$ ) containing 2 mM EDTA, 2 mM EGTA, $0.25 \mathrm{M}$ sucrose and $2 \mathrm{mM}$ phenylmethylsulfonyl fluoride (PMSF) with a Polytron homogenizer, and the homogenate was centrifuged at 105,000x $g$ for $60 \mathrm{~min}$ at $4{ }^{\circ} \mathrm{C}$. The resultant cytosol fraction was loaded onto a $0.8 \times 3 \mathrm{~cm}$ column of DEAE cellulose (DE52. Whatman, Ltd., Maidstone, U.K.) pre-equilibrated with 20 $\mathrm{mM}$ Tris- $\mathrm{HCl}$ buffer ( $\mathrm{pH}$ 7.5) containing 2 mM EDTA. $0.5 \mathrm{mM}$ EGTA. $2 \mathrm{mM}$ PMSF and $50 \mathrm{mM}$ 2-mercaptoethanol. Columns were washed with $6 \mathrm{ml}$ of the above buffer. Protein kinase $\mathrm{C}$ was eluted with $2 \mathrm{mi}$ of the buffer containing $0.1 \mathrm{M} \mathrm{NaCl}$. The $105,000 \times \mathrm{g}$ pellet was resuspended in the original volume of homogenizing buffer containing $0.3 \%$ $(v / v)$ Triton $X-100$ and gently stirred at $4^{\circ} \mathrm{C}$ for $60 \mathrm{~min}$. The suspension was centrifuged at $105.000 \times \mathrm{g}$ for $60 \mathrm{~min}$ at $4^{\circ} \mathrm{C}$. The resulting supernatant was subjected to DEAE cellulose (DE52) column chromatography just as described above. In this case, however, the equilibration buffer contained $0.02 \%$ Triton $X-100$. Protein kinase $C$ was eluted with the buffer containing $0.1 \mathrm{M} \mathrm{NaCl}$. Protein kinase activity was determined by incubating 2.5 $\mathrm{nmol}\left[\gamma-{ }^{32} \mathrm{P}\right]$ ATP, $30 \% \mathrm{~g}$ histone, $500 \mathrm{nmol}$ magnesium acetate, $6.25 \mu \mathrm{mol} 2$-mercaptoethanol and 50 "l of crude enzyme preparation in the presence or absence of $3.1 \mu \mathrm{g}$ phosphatidylserine. $300 \mathrm{nmol} \mathrm{CaCl}_{2}$ and 3.75 pmol TPA in $20 \mathrm{mM}$ Tris- $\mathrm{HCl}(\mathrm{pH} 7.5)$ buffer in a total volume of $125 \mu \mathrm{l}$. The reaction was started by the addition of [ $r-32 P]$ ATP. Incubation was carried out at $37^{\circ} \mathrm{C}$ for $3 \mathrm{~min}$; then the reaction was stopped by transferring a $50 \mu l$ aliquot of the incubation mixture onto $6.25-\mathrm{cm}^{2}$ pieces of Whatman cellulose phosphate paper (P81). The pieces of paper were washed 4 times with deionized water, twice with acetone, and once with petroleum-ether. The radioactivity on each piece of paper was determined by scintillation counting.

Materials: $C D-1$ mice were obtained from Charles River, Atsugi, Japan: C57BL/6 mice were from Clea, Tokyo, Japan; SENCAR mice were from Shizuoka Agricultural Cooperative Association for Laboratory Animals, Hamamatsu, Japan. TPA was purchased from Chemicals for Cancer Research, Inc., Chicago, IL; L- $\alpha$-phosphatidyl-L-serine. ATP, histone (type III-S), PMSF were from Sigma Chemical Co., St. Louis, MO: $\left[{ }^{3} \mathrm{H}\right]$ TPA (12.7 $\mathrm{Ci} / \mathrm{mmol})$ and $[r-32 \mathrm{P}]$ ATP were from New England Nuclear, Boston, MA; DL- $\left[1-{ }^{14} \mathrm{C}\right]$ ornithine $(61 \mathrm{mCi} / \mathrm{mmol})$ was from Amersham, Buckinghamshire, U.K.

\section{Results}

Epidermal protein kinase $\mathrm{C}$ activities of C57BL/6 and CD-1 mice were also compared. Since protein kinase $\mathrm{C}$ can be degraded by proteases to generate a $\mathrm{Ca}^{2+}$ and phospholipid-independent kinase designated as $M$ kinase (12), the enzyme preparation was prepared in the presence of the protease inhibitor PMSF. Protein kinase $C$ activities of the $105.000 \times \mathrm{g}$ supernatant observed in the presence of $\mathrm{Ca}^{2+}$ and phosphatidylserine either with or without TPA were not significantly different between C57BL/6 and CD-1 mice (Table 1). On the other hand, protein kinase $C$ activity of the $105,000 \times \mathrm{g}$ pellet of 
Table 1. Epidermal protein kinase $C$ activities of $C 57 \mathrm{BL} / 6$ and $\mathrm{CD}-1$ mice

\begin{tabular}{|c|c|c|c|c|}
\hline \multirow{3}{*}{ Additionc } & \multicolumn{4}{|c|}{ Protein kinase activity's (cpm/ $\mu$ g protein) } \\
\hline & \multicolumn{2}{|c|}{ CD-1 } & \multicolumn{2}{|c|}{$\mathrm{C} 57 \mathrm{BL} / 6$} \\
\hline & $\begin{array}{l}105,000 \times \mathrm{g} \\
\text { supernatant }\end{array}$ & $\begin{array}{c}105,000 \times \mathrm{g} \\
\text { pellet }\end{array}$ & $\begin{array}{l}105,000 \times g \\
\text { supernatant }\end{array}$ & $\begin{array}{c}105,000 \times g \\
\text { pellet }\end{array}$ \\
\hline None & $47 \pm 9$ & $42 \pm 21$ & $60 \pm 5$ & $90 \pm 21$ \\
\hline $\mathrm{Ca}^{2+}$ & $65 \pm 3$ & $68 \pm 25$ & $86 \pm 8$ & $274 \pm 20^{*}$ \\
\hline $\mathrm{Ca}^{2++}+\mathrm{PS}$ & $1143 \pm 61$ & $2928 \pm 613$ & $1370 \pm 39$ & $7617 \pm 331 *$ \\
\hline $\mathrm{Ca}^{2+} \div \mathrm{PS}+\mathrm{TPA}$ & $1159 \pm 148$ & $5109 \pm 385$ & $1353 \pm 15$ & $9553 \pm 223^{*}$ \\
\hline
\end{tabular}

The $105.000 \times \mathrm{g}$ supernatant and the Triton $X-100$-treated $105,000 \times \mathrm{g}$ pellet of epidermal homogenates were subjected to DEAE cellulose (DE52) column chromatography, and the fractions eluted with $0.1 \mathrm{M}$ $\mathrm{NaCl}$ were used as crude enzyme preparations. In each experiment, the epidermal $10.5000 \times \mathrm{g}$ supernatant and $10,5000 \times g$ pellet were prepared from a pool of epidermis obtained from 5-6 mice. Similar experiments were performed three times, and the data obtained were reproducible. bMean $\pm S$.E. of triplicate determinations. $300 \mathrm{nmol} \mathrm{Ca}^{2+}, 3.1 \mu \mathrm{g}$ phosphatidylserine (PS), $3.75 \mathrm{pmol}$ TPA, in $125 \mu \mathrm{l}$ assay medium (final volume). "Significantly different $(P<0.05)$ from the corresponding values of $C D-1$ mice.

Table 2. Specific linding of $\left[{ }^{3} \mathrm{H}\right] \mathrm{TPA}$ to particulate fractions of epidermal homogenates of $\mathrm{C} 57 \mathrm{BL} / 6$ and $\mathrm{CD}-1$ mice

\begin{tabular}{cccc}
\hline & C57BL/6 & CD - 1 \\
$\mathrm{~K}_{\mathrm{a}}(\mathrm{nM})$ & $-\frac{0.7}{2}-7$ & 0.7 \\
$\mathrm{~B}_{\max }(\mathrm{pmol} / \mathrm{mg}$ protein) & 4.4 & 4.6 \\
\hline
\end{tabular}

a In each experiment, epidermal particulate fraction was prepared from a pool of epidermis obtained from 15 mice. Similar experiments were performed three times and the data obtained were reproducible. $K_{1}$ and $B_{\max }$ were obtained from the saturation curve of the specific binding of $\left[{ }^{3} \mathrm{H}\right] \mathrm{TPA}$.

$\mathrm{C} 57 \mathrm{BL} / 6$ mice was significantly higher than that of CD-1 mice.

Specific binding of $\left[{ }^{3} \mathrm{H}\right]$ TPA to its receptor site in the epidermis was compared between C57BL/6 and CD-1 mice. Since it is known that phorbol ester binding remains intact after protease treatment (13-15), the epidermal particulate fraction was prepared in the absence of protease inhibitor. Linear increase in the specific binding was observed with the particulate fraction obtained either from $\mathrm{C} 57 \mathrm{BL} / 6$ or $\mathrm{CD}-1$ mice in the concentration range of 0 to $100 \mathrm{\mu g} / \mathrm{ml}$ protein (data not shown). Thus, the following experiments were performed with $60 \mathrm{~kg} / \mathrm{ml}$ protein. In either strain of mice, the binding of $\left[{ }^{3} \mathrm{H}\right] T P A$ reached apparent equilibrium within $20 \mathrm{~min}$ at $39^{\circ} \mathrm{C}$, and specific binding was apparently saturable (data not shown). As shown in Table 2, the dissociation constant $\left(K_{d}\right)$ and the maximal number of binding sites $\left(B_{\max }\right.$ ) were similar in both strains of mice.
We next determined whether epidermal responses of ODC induction to a topical application of TPA are different in $C 57 \mathrm{BL} / 6$. CD-1 and SENCAR mice (Fig. 1). Irrespective of the mouse strain, ODC was maximally induced at 5 to $7 \mathrm{hr}$ after TPA application (data not shown). Therefore, epidermal ODC activity was determined at $5 \mathrm{hr}$ following TPA application. At any doses of TPA, TPAinduced epidermal ODC activity of C57BL/6 mice was always higher than those of SENCAR and CD-1 mice. Maximal induction of epidermal ODC by TPA was also highest in $\mathrm{C} 57 \mathrm{BL} / 6$ mice among these three strains of mice. The results were highly reproducible.

\section{Discussion}

The present results clearly show that no difference exists in the specific binding of $\left[{ }^{3} \mathrm{H}\right]$ TPA to its membrane receptor sites on the epidermis between the tumor promotionsusceptible CD-1 mice and the tumor pro- 


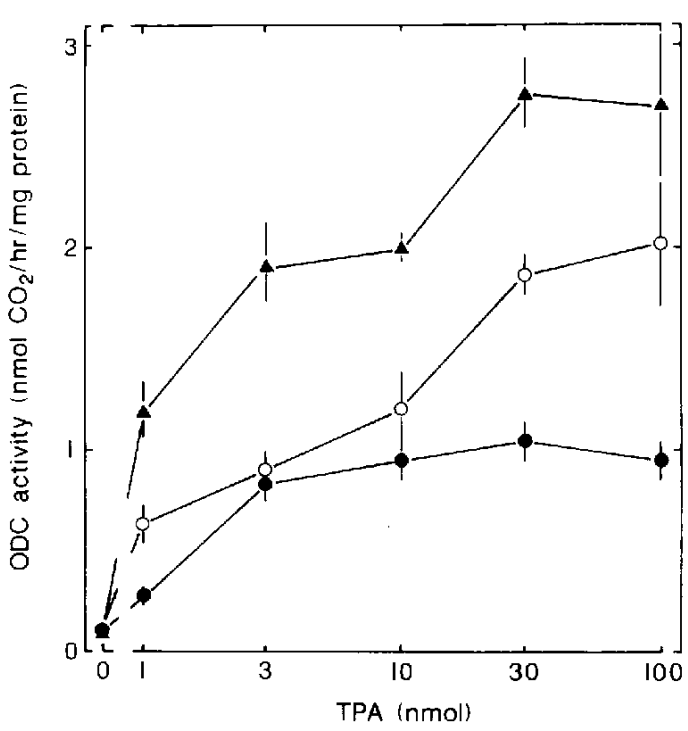

Fig. 1. Dase-response relationships of epidermal ODC induction by a topical application of TPA in C57BL/6, CD-1 and SENCAR mice. Mice were topically treated with the indicated amounts of TPA and killed for the determination of ODC activity $5 \mathrm{hr}$ after the TPA application. Each value is the meant S.E. of individual determinations from 5 mice. C57BL/6 mice; CD-1 mice; O, SENCAR mice.

motion-resistant $\mathrm{C} 57 \mathrm{BL} / 6$ mice. Wheldrake et al. also reported that the binding characteristics of $\left[{ }^{3} \mathrm{H}\right]$ phorbol-12,13-dibutyrate to the particulate fraction of mouse skin from tumor promotion-sensitive Swiss mice are indistinguishable from those of tumor promotion-resistant Balb/c mice (16). Protein kinase $\mathrm{C}$ activities detected in the epidermal $105.000 \times g$ supernatant were also similar in both strains of mice. Garte et al. (17) reported that the cytosolic protein kinase $C$ activity of C57BL/6 mice was not significantly different from that of SENCAR mice, consistent with our present results with $\mathrm{C} 57 \mathrm{BL} / 6$ mice and CD-1 mice. Garte et al. (17), however, did not investigate the protein kinase $\mathrm{C}$ activities of the particulate fractions. As shown in our present study, protein kinase $C$ activity of the epidermal $105,000 \times \mathrm{g}$ pellet was significantly higher in $\mathrm{C} 57 \mathrm{BL} / 6$ mice than in $\mathrm{CD}-1$ mice. Since it is plausible that the membrane receptor site for TPA is membrane-bound protein kinase $\mathrm{C}$ itself, the data of $\left[{ }^{3} \mathrm{H}\right]$ TPA binding and protein kinase $C$ activity in the particu- late fraction would correspond to each other. The differences in the procedures taken to make the particulate fraction for the binding experiments and the enzyme preparation or the assay conditions may cause the apparent dissociation in the experimental results. In any case, resistance of $\mathrm{C} 57 \mathrm{BL} / 6$ mice to TPAinduced tumor promotion can be explained neither by the difference in $\left[{ }^{3} \mathrm{H}\right]$ TPA binding nor protein kinase $C$ activity. At present, we cannot exclude the possibility that the level of the endogenous substrate protein is different between $\mathrm{C} 57 \mathrm{BL} / 6$ mice and $\mathrm{CD}-1$ mice. It has been well established that the protein kinase $\mathrm{C}$ activation by TPA is prerequisite for $\operatorname{ODC}$ induction $(6,7,18)$, and the ODC induction is essential for the TPAinduced skin tumor promotion (4, 5). Response of epidermal ODC induction by a topical application of TPA was highest in $\mathrm{C} 57 \mathrm{BL} / 6$ mice among these three strains of mice, indicating that the inducibility of ODC by TPA does not correlate with the susceptibility of mice to TPA-induced tumor promotion. These results suggest that the mechanism of the difference in susceptibility of C57BL/6, CD-1 and SENCAR mice to the tumor-promoting action of TPA resides in a step distal to or other than the protein kinase $C$ activation and ODC induction.

Acknowledgments: This work was supported in part by Grants-in-Aid for Cancer Research from the Ministry of Education. Science and Culture of Japan and by Grants-in-Aid for Cancer Research from the Ministry of Health and Welfare of Japan.

\section{References}

1 Slaga, T.J. and Fischer, S.M.: Strain differences and solvent effects in mouse skin carcinogenesis experiments using carcinogens, tumor initiators and promoters. Prog. Exp. Tumor Res. 26, 85109 (1983)

2 Reiners, J.J., Nesnow, S. and Slaga, T.J.: Murine susceptibility to two-stage skin carcinogenesis is influenced by the agent used for promotion. Carcinogenesis 5, 301-307 (1984)

3 Digiovanni, J., Prichett, W.P., Decina, P.C. and Diamond, L.: DBA/2 mice are as sensitive as SENCAR mice to skin tumor promotion by $12-$ O-tetradecanoylphorbol-13-acetate. Carcinogenesis 5, 1493-1498 (1984)

4 Blumberg, P.M.: In vitro studies in the mode of action of the phorbol ester potent tumor pro- 
moters. CRC Crit. Rev. Toxicol. 9, 199-234 (1981)

5 O'Brien, T.G.: The induction of ornithine decarboxylase as an early. possibly obligatory. event in mouse skin carcinogenesis. Cancer Res. 36, 2644-2653 (1976)

6 Castagna, M., Takai, Y., Kaibuchi, K., Sano, K., Kikkawa, $U$. and Nishizuka, $Y$.: Direct activation of calcium-activated, phospholipid-dependent protein kinase by tumor-promoting phorbol esters. J. Biol. Chem. 257, 7847-7851 (1982)

7 Nishizuka, Y.: The role of protein kinase $C$ in cell surface signal transduction and tumor promotion. Nature 308,693-697 (1984)

8 Nakadate, T., Yamamoto, S., Aizu, E. and Kato, R.: Inhibition of 12-O-tetradecanoylphorbol-13acetate-induced tumor promotion and epidermal ornithine decarboxylase activity in mouse skin by palmitoylcarnitine. Cancer Res, 46, 15891593 (1986)

9 O'Brien, T.G., Simsiman, R.C. and Boutwell, R.K.: Induction of the polyamine-biosynthetic enzymes in mouse epidermis by tumorpromoting agents. Cancer Res. 35, 1662-1670 (1975)

10 Nakadate, T., Yamamoto, S., Ishii, M. and Kato, R.: Inhibition of 12-O-tetradecanoylphorbol-13acetate-induced epidermal ornithine decarboxylase activity by phospholipase $A_{2}$ inhibitors and lipoxygenase inhibitor. Cancer Res. 42, 28412845 (1982)

11 Nakaki, T., Mita, S., Yamamoto, S., Nakadate, T. and Kato, R.: Inhibition by palmitoylcarnitine of adhesion and morphological changes in $\mathrm{HL}-60$ cells induced by 12-0-tetradecanoylphorbol-13acetate. Cancer Res. 44, 1908-1912 (1984)

12 Kishimoto, A., Kajikawa, N., Shiota, M. and Nishizuka, Y.: Proteolytic activation of ca!ciumactivated. phospholipid-dependent protein kinase by calcium-dependent neutral protease. J. Biol. Chem. 258, 1156-1164 (1983)

13 Huang, K.-P. and Huang, F.L.: Conversion of protein kinase $\mathrm{C}$ from a $\mathrm{Ca}^{2+}$-dependent to an independent form of phorbol ester-binding protein by digestion with trypsin. Biochem. Biophys. Res. Commun. 139, 320-326 (1986)

14 Lee, M.-H. and Bell, R.M.: The lipid binding. regulatory domain of protein kinase C. J. Biol. Chem. 261, 14867-14870 (1986)

15 Nakadate, T., Jeng, A.Y. and Blumberg, P.M.: Effect of phospholipid on substrate phosphorylation by a catalytic fragment of protein kinase C. J. Biol. Chem. 262, 11507-11513 (1987)

16 Wheldrake, J.F., Marshal!, J., Ramli, J. and Murray, A.W.: Skin carcinogenesis and promoter binding characteristics in different mouse strains. Carcinogenesis 3, 805-807 (1982)

17 Garte, S.J., Edinger, F. and Mufson, A.: Phorbol ester activation of epidermal protein kinase $C$ from tumor promotion sensitive and resistant mouse strains. Cancer Lett. 29, 215-221 (1985)

18 Sasakawa, N., Ishii, K., Yamamoto, S. and Kato, R.: Induction of ornithine decarboxylase activity by 1 -oleoyl 2 -acetyl glycerol in isolated mouse epidermal cells. Biochem. Biophys. Res. Commun. 128, 913-920 (1985) 